\title{
Behartiging van het onderwijs in coronatijd in Nederland en Zuid-Afrika: een vergelijkende studie
}

\begin{tabular}{|c|c|}
\hline \multicolumn{2}{|c|}{$\begin{array}{l}\text { Authors: } \\
\text { Nicolaas A. Broer }{ }^{1} \text { (D) } \\
\text { Johannes L. van der Walt }{ }^{2} \\
\text { Charl C. Wolhuter }{ }^{2}\end{array}$} \\
\hline \multicolumn{2}{|c|}{$\begin{array}{l}\text { Affiliations: } \\
\text { 1Research Centre, Driestar } \\
\text { Christian University of } \\
\text { Teacher Education, Gouda, } \\
\text { The Netherlands }\end{array}$} \\
\hline \multicolumn{2}{|c|}{$\begin{array}{l}{ }^{2} \text { Unit for Education and } \\
\text { Human Rights in Diversity, } \\
\text { Faculty of Education, } \\
\text { North-West University, } \\
\text { Potchefstroom, South Africa }\end{array}$} \\
\hline \multicolumn{2}{|c|}{$\begin{array}{l}\text { Corresponding author: } \\
\text { Nicolaas Broer, } \\
\text { n.a.broer@driestar-educatief. } \\
\text { nl }\end{array}$} \\
\hline \multicolumn{2}{|c|}{$\begin{array}{l}\text { Dates: } \\
\text { Received: } 05 \text { Oct. } 2021 \\
\text { Accepted: } 15 \text { Nov. } 2021 \\
\text { Published: } 19 \text { Jan. } 2022\end{array}$} \\
\hline \multicolumn{2}{|c|}{$\begin{array}{l}\text { How to cite this article } \\
\text { Broer, N.A., Van der Walt, } \\
\text { J.L. \& Wolhuter, C.C., 2022, } \\
\text { 'Behartiging van het } \\
\text { onderwijs in coronatijd in } \\
\text { Nederland en Zuid-Afrika: } \\
\text { een vergelijkende studie', } \\
\text { HTS Teologiese Studies/ } \\
\text { Theological Studies 78(4), } \\
\text { a7173. https://doi. } \\
\text { org/10.4102/hts.v78i4.7173 }\end{array}$} \\
\hline \multicolumn{2}{|c|}{$\begin{array}{l}\text { Copyright: } \\
\text { (C) 2022. The Authors. } \\
\text { Licensee: AOSIS. This work } \\
\text { is licensed under the } \\
\text { Creative Commons } \\
\text { Attribution License. }\end{array}$} \\
\hline \multicolumn{2}{|l|}{ Read online: } \\
\hline 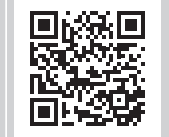 & $\begin{array}{l}\text { Scan this QR } \\
\text { code with your } \\
\text { smart phone or } \\
\text { mobile device } \\
\text { to read online. }\end{array}$ \\
\hline
\end{tabular}

Managing education during the pandemic in the Netherlands and South Africa: A comparative study. Optimism has reigned supreme for a long time regarding the potential of education (schooling) to address the many societal ailments that humankind has had to deal with. The outbreak of the COVID-19 pandemic in March 2020 shifted all such aspirations to the back-burner. Now, after just more than a year after the initial outbreak of the pandemic, the question can be raised whether those who managed the pandemic in the educational context followed the correct policies and instituted the correct (ethical, moral) measures in combatting the pandemic. This comparison between the situation in the Netherlands and South Africa reveals that although the role-players in both countries had a good understanding of the situation and of their duties in such conditions, they tended to treat education as just another facet of society, thereby demonstrating a lack of empathy with the unique demands of education (schooling).

Contribution: In this article, the authors investigate the governance performance of two different countries during the first year of the COVID-19 pandemic concerning education and judge that performance based on a Biblically driven ethical-moral-pedagogical framework.

Keywords: corona crisis; education; education system; ethics; morality; government; South Africa; the Netherlands; comparative study.

\section{Introductie en probleemstelling}

In de moderne samenleving wordt het onderwijs gezien als een middel dat kan bijdragen aan het oplossen van allerlei problemen, zoals werkeloosheid, economische achterstelling, drugsmisbruik en verkeersdoden. Het grote geloof in de kracht van het onderwijs zorgde sinds het midden van de twintigste eeuw wereldwijd voor een aanzienlijke uitbreiding ervan. De COVID-19 pandemie in 2020-2021 doorkruiste deze optimistische opvatting over het onderwijs en deed er afbreuk aan. De sluiting van scholen en andere onderwijsinstellingen als gevolg van de pandemie heeft 91 procent van de schoolbevolking in de wereld geraakt (UNESCO 2020a, 2020b). In maart 2021, een jaar na de uitbraak van de pandemie, waren in 26 landen alle onderwijsinstellingen nog gesloten (UNESCO 2021). Door de gevolgen van de pandemie ontstond bij de auteurs de volgende onderzoeksvraag:

Hebben de verantwoordelijken voor het onderwijs gedurende het eerste jaar van de crisisperiode het schoolse onderwijs op de meest effectieve, empathische en liefdevolle wijze bestuurd en behartigd?

Het antwoord op die vraag is niet voor de hand liggend, omdat een veelheid van factoren in aanmerking moet worden genomen. Om toch een antwoord te kunnen geven, hebben de auteurs besloten om het overheidsoptreden gedurende het eerste jaar van de pandemie (maart 2020-juni 2021) met betrekking tot het schoolse onderwijs in twee heel verschillende, maar historisch verbonden, landen met elkaar te vergelijken, namelijk Nederland en Zuid-Afrika. De rationale achter deze keuze is: Nederland is geografisch gezien een klein land, terwijl Zuid-Afrika geografisch relatief groot is; Nederland is een hoogontwikkeld land, terwijl Zuid-Afrika een ontwikkelingsland is. Nederland heeft een kleine, etnisch-cultureel gezien betrekkelijk homogene (hoewel in toenemende mate heterogene), bevolking, terwijl Zuid-Afrika een grote en heel diverse bevolking heeft; Nederland heeft één officiële taal, terwijl Zuid-Afrika er elf (met de gebarentaal erbij: twaalf) heeft; Nederland is lid van de Europese Unie en Zuid-Afrika van de Afrika-unie; het staatsbestel in het Koninkrijk der Nederlanden is een constitutionele monarchie en Zuid-Afrika heeft een republikeins regeringsstelsel, terwijl beide ook gelden als een parlementaire democratie. Deze verschillen maken het mogelijk om de manier waarop de overheden onderwijskwesties tijdens de coronacrisis (maart 2020 tot mei 2021) hebben behartigd zinvol met elkaar te vergelijken. Daaruit kunnen lessen worden geleerd die van belang zijn met het oog op toekomstige crises. 
De uiteenzetting begint met een verduidelijking van de onderzoeksmethode, waarbij de vergelijkende methode in de onderwijskunde een accent krijgt. Dit accent wordt gelegd omdat het artikel zich toespitst op het onderwijs in twee verschillende landen. Vervolgens wordt een ethisch-moreelpedagogisch referentiekader beschreven dat later gebruikt wordt om de situaties in de beide landen te ontleden en te beoordelen. Het referentiekader bevat ook een bespreking van de rol en de bevoegdheden van de overheid ten opzichte van het onderwijs. Daarna worden de situaties in Nederland en Zuid-Afrika afzonderlijk besproken. Het gaat daarin over de hantering van onderwijskwesties door de overheid gedurende het eerste jaar van de coronacrisis. Vervolgens worden beide situaties ontleed en beoordeeld in het licht van het referentiekader. Tot slot worden conclusies getrokken.

\section{Onderzoeksmethode}

In dit artikel worden twee grote gegevensbestanden via de interpretatief-constructivistische methode geanalyseerd, vergeleken en beoordeeld. In de interpretatieve of verklarende fase van het onderzoek werd al het onderzoeksmateriaal dat nodig was om een vergelijking te kunnen maken bijeengebracht. Gegevens die in het kader van de vergelijking niet van belang leken te zijn, werden niet in deze fase betrokken (vgl. Thanh \& Thanh 2015:25). In de tweede fase, de constructivistische, werd het onderzoeksmateriaal zó geconstrueerd en opgebouwd dat er vergelijkbare situatiebeschrijvingen ontstonden. Deze werkwijze komt overeen met het constructivistische uitgangspunt dat de werkelijkheid (hier in het raamwerk van een Schriftuurlijke ontologie en kosmologie) ook sociaal geconstrueerd wordt (Thanh \& Thanh 2015:25) en daarmee bruikbaar is voor onderzoeksdoeleinden (Mayes \& De Freitas 2007:17). Om een zinvolle vergelijking mogelijk te maken, werd bij de constructie van de situatiebeschrijvingen in ieder geval aandacht besteed aan de rol van de overheid in het staatsbestel en de manier waarop de overheid de onderwijszaken tijdens de pandemie behartigde.

Het internationaal vergelijkend perspectief is een breed aanvaarde en gebruikte methode om maatschappelijke vraagstukken, ook die op onderwijsgebied, te belichten (Crossley 2014). Het doelbewuste, systematische vruchtbaar maken van buitenlandse ervaringen om binnenlandse onderwijsvraagstukken aan te pakken, heeft een geschiedenis van twee eeuwen (Wolhuter 2021). In de huidige globaliserende wereld waarin landen met elkaar wedijveren en waarin economieën in grote mate worden aangedreven door het produceren en aanwenden van nieuwe kennis, heeft het identificeren van goede onderwijspraktijken en goed onderwijsbeleid op internationaal niveau nieuwe waarde gekregen (vgl. Wiseman 2010).

De vakwetenschap Vergelijkende en Internationale Onderwijskunde heeft een stelregel die altijd in acht moet worden genomen als onderwijspraktijken en -beleidsmaatregelen van het ene onderwijsstelsel worden overgezet naar het andere, om dat te verbeteren (Stromquist 2002). Een element van een onderwijsstelsel moet worden beschouwd als een integraal onderdeel van een organisch geheel dat bestaat uit veel verschillende componenten (zoals curriculum, doelstellingen, leerlingen, leraren, ouders en schoolbesturen) en dat in een bepaalde maatschappelijke context (geografie, demografie, economie, sociaal en politiek systeem, godsdienst en levens-/ wereldbeschouwing) is ontstaan. Verschillen en overeenkomsten in onderwijsstelsels en hun maatschappelijke contexten moeten dus altijd in ogenschouw worden genomen voordat het succes van het ene onderwijsstelsel kan worden voorgehouden aan het andere.

Ten eerste wordt nu omschreven volgens welke 'soort' ethiek of moraliteit het hanteren van de onderwijszaken in de twee landen wordt geëvalueerd. Ten tweede worden enkele gedachten gewijd aan de rol van de staat/overheid, die in de periode van de pandemie in beide landen een bepalende rol heeft gespeeld. Ten slotte wordt aandacht besteed aan de plek en de rol van het schoolse onderwijs als samenlevingskring, aangezien in dit artikel het behartigen van onderwijskwesties centraal staat.

\section{Theoretisch raamwerk Een ethisch-moreel-pedagogisch referentiekader}

De analyse, vergelijking en beoordeling die in dit artikel aan de orde komen, kunnen worden uitgevoerd aan de hand van een veelheid aan 'ethieken' of 'moraliteitsraamwerken', waaronder situatie-ethiek, plichtsethiek, deugdenethiek en integriteitsethiek. Omdat het niet mogelijk is om hier alle ethieken in één referentiekader te verwerken, wordt volstaan met de keuze voor de situatie-ethiek. Deze keuze is gepast, omdat het in dit artikel gaat om de analyse, vergelijking en beoordeling van situaties, namelijk de onderwijssituaties in Nederland en Zuid-Afrika. De keuze wordt bovendien ingegeven door het feit dat de situatie-ethiek ook elementen van deplichtsethiek, de deugdenethiek en deintegriteitsethiek omvat.

Over de betekenis van de termen 'ethisch', 'moreel' en 'zedelijk' bestaat verschil van mening. Sommigen beschouwen deze termen als synoniem. Anderen doen dat niet en vatten het ethische op als gedragsregels of normen die iemand van buitenaf opgelegd krijgt (zoals een beroepscode), terwijl het morele duidt op de verinnerlijking van zulke regels en normen. Vanwege de beperkingen die een artikel als dit met zich meebrengt, worden de drie termen niet afzonderlijk en uitgebreid besproken, maar beschouwd als synoniemen. Ze verwijzen namelijk alle naar hoe wij ons behoren te gedragen.

Stoker (1967:236) maakt in wat zedelijk goed en behoorlijk is een onderscheid tussen algemene normen (zedenwetten) en contingente (evenredige) normen. De algemene zedelijke normen vormen een inherent onderdeel van de wetsorde die God voor de schepping heeft bepaald. De implicatie daarvan is dat de algemene zedelijke normen elementen bevatten van de opdrachtsethiek, plichtsethiek, deugdenethiek en doelethiek (Frame 2008:14). De contingente normen houden 
daarentegen verband met bepaalde situaties en gebeurtenissen op een bepaalde plaats en op een bepaald tijdstip, zoals de uitbraak van een pandemie in een land. Bij toepassing van contingente normen moet, aldus Stoker, gelet worden op de tekenen en de eisen van de tijd. Er is een tijd om het ene te doen en het andere niet. Wat in een bepaalde situatie het zwaarste is, moet het zwaarste wegen. De algemene normen en de contingente normen mogen echter niet van elkaar worden losgemaakt. Het hanteren van contingente normen (bv. als zich een pandemie voordoet) is een kwestie van wisselwerking tussen de door God gegeven algemene zedelijke normen enerzijds en de vereisten van de betreffende situatie anderzijds. Het is niet de loutere toepassing van een algemene norm op die situatie (Thompson 2018:59).

Situatie-ethiek verschilt van casuïstiek, want die komt erop neer dat ieder zelf moet besluiten wat in een bepaalde situatie gedaan moet worden en dus steeds opnieuw 'het morele wiel' moet uitvinden. Bij casuïstiek worden incidentele besluiten genomen die slechts betrekking hebben op de betreffende situatie (Geisler 2010:22). Daartegenover speelt in de situatie-ethiek steeds de vraag: 'Wat is de beste manier of het beste optreden om het doel van God te bereiken?' (Frame 2008:33). Bij de overweging of het optreden in een bepaalde situatie zedelijk/moreel goed is, geeft Vorster (2017:158-160) enkele richtlijnen. Ten eerste moet worden gelet op de uitkomsten van het optreden of de daad. Het optreden moet een goede uitkomst hebben voor iedereen die daarbij betrokken is. Ten tweede moet worden vastgesteld of de daad wordt ingegeven door liefde, mededogen en empathie (overeenkomstig het liefdegebod; Matt 7:12; Gal 5:14). Ten derde moet worden bezien of de handelende persoon de houding en de gezindheid van Jezus Christus vertoont. Dit laatste komt overeen met de visie van Mitchell (2013:18) dat Christenen (in dit geval Christenopvoeders) zich bezighouden met de vraag in hoeverre de gezindheid, het gedrag en het karakter van de handelende persoon gericht is of was op de dienst aan de drie-enige God door Jezus Christus en of het de inwerking van de Heilige Geest vertoont. De vraag is dus of de handelende persoon op authentieke wijze, dat wil zeggen integer, is opgetreden: was het optreden van de persoon of instantie oprecht, betrouwbaar, consequent, trouw aan zichzelf en aan beginselen? Liautaud (2021:163) stelt het integriteitsbeginsel als volgt: 'Authenticity is earned through ethical decision-making and seeking others' views'. Verder moet in ogenschouw worden genomen dat moreel optreden het welzijn van zowel individuen als een groep (bv. een hele natie) kan raken en beïnvloeden (Paley 2021:171). De vraag is dus of het optreden mededogen en liefde aan de betrokkenen toont en hen dient (Koonce 2018:105).

Kortom, het perspectief van de situatie-ethiek helpt om aandacht te geven aan wat in een bepaalde situatie dienstig is, aan wat tot ieders bestwil dient en aan wat overeenkomstig de eisen van de opdrachts-, plichts- en deugdenethiek - de eer van God zoekt en bevordert.
Poythress (2006:209-210) vat de rol, taak en plaats van de situatie-ethiek als volgt samen. Het normatieve perspectief ervan is gericht op de normen die aangeven wat als goed en kwaad beschouwd kan worden. Het persoonlijke perspectief ervan is gericht op de gezindheid en de motieven die achter het handelen schuilgaan. Het situatieperspectief ervan is gericht op wat vruchtbaar en nuttig is in de betreffende situatie. En dan stelt hij tot slot: 'Because God issues the norms, governs the people, and governs the situation, all three in principle (should) exist in harmony'.

\section{De rol, plaats en taak van de overheid}

Omdat dit artikel gericht is op de wijze waarop de overheden in twee landen de onderwijssituatie hebben behartigd, wordt hier aandacht besteed aan de principiële rol, plaats en taak van de overheid. Het uitgangspunt hierbij is, volgens Frame (2008:48), dat er in de rol en het optreden van de overheid een evenwicht moet zijn tussen enerzijds de handhaving van wet en orde en anderzijds de vrijheid van de burgers. Hoewel God de overheid gezag geeft om recht en orde te handhaven (Rm 13:1-6), is dat gezag niet absoluut. Het wordt begrensd door het hogere gezag van God zelf, waaraan de overheid gehoorzaam dient te zijn. De overheid dient dus niet tiranniek op te treden, maar behoort diegenen over wie zij gezag uitoefent, te dienen zoals ook Jezus Christus zelf gediend heeft (Matt 20:25-28). Zij behoort op te treden op een manier die de belangen van de burgers in het land bevordert. Als de overheid optreedt op een manier die de burgers benadeelt of hun vrijheden onnodig beperkt, overschrijdt zij de grenzen van haar bevoegdheid en dringt daarmee andere samenlevingsverbanden binnen, zoals dat van de school (Strauss 2009:781). In zulke gevallen ontaardt de staat in een te ver doorgeslagen verzorgingsstaat. Om dit te vermijden, moet de overheid de nationale staat waarover zij gezag heeft, zien als een morele gemeenschap waarin het overleven van de groep wordt gewaarborgd door loyaliteit, sympathie en gedeelde zorg (Mitchell 2013:73). Aansluitend bij wat hierboven over situatie-ethiek is gezegd, kan worden gesteld dat de overheid de zaken van land en volk moet regelen in het algemeen belang (Pinker 2019:27). Daarmee wordt de stabiliteit van de groep verzekerd (Lahti \& Weinstein 2005:56).

\section{De rol, plaats en taak van het onderwijs}

In beginsel speelt de overheid geen rol in de opvoeding van kinderen en jongeren buiten schoolverband, behalve als er sprake is van verwaarlozing of criminaliteit. De meeste overheden hebben echter wel het beheer en de zeggenschap over openbare scholen (gekregen). Daarom kan de landsoverheid, vooral in tijden van crisis, zelfs tegen de wensen en belangen van ouders en leerlingen in, besluiten over het onderwijs nemen en afdwingen. Hoofdzakelijk vanuit financiële overwegingen lijkt het onvermijdelijk dat de overheid zeggenschap heeft en uitoefent over het schoolse onderwijs. Maar in de huidige gedifferentieerde samenleving is die zeggenschap tevens een overtreding van het soevereiniteitsbeginsel. Strauss (2009:779) formuleert deze visie als volgt: 'When the 
principle of sphere sovereignty is accepted, every sphere of a differentiated society receives its proper social space - without being subsumed to another societal sphere'.

Schools onderwijs als samenlevingskring functioneert binnen het logisch-analytische aspect van de werkelijkheid. Het wordt beheerst door theoretisch-analytisch denken en abstractie (Heiberg 1970:44). Wat er dus in een klaslokaal wordt onderwezen en geleerd, wordt aangestuurd door het logische aspect van de werkelijkheid, in eerste instantie door analyse (Strauss 2009:93), door onderscheid tussen het logische en het onlogische en daarna ook door synthese van wat eerst onderscheiden werd. Ideaal gesproken, behoort een school (in de vorm van het schoolbestuur) zijn eigen besluiten te kunnen nemen met erkenning dat de overheid de taak heeft om de orde in de staat te handhaven. In de praktijk werkt het echter niet op die manier. In crisisomstandigheden staan de scholen, zelfs onafhankelijke niet-staatsscholen, onder het bewind van de overheid.

\section{Resultaten: het behartigen van het onderwijs \\ De situatie in Nederland}

In het Nederlandse staatsbestel wordt de regering gevormd door de koning en de ministers. De ministers bepalen gezamenlijk het regeringsbeleid en zijn daar ook politiek verantwoordelijk voor. Zij zijn ook politiek verantwoordelijk voor de uitspraken van de koning, die slechts in naam regeert. De ministers worden geacht zich te houden aan de besluiten die in de ministerraad worden genomen. Omdat het kabinet (de gezamenlijke ministers) geacht wordt met één mond te spreken, bracht de minister-president gedurende de coronaperiode, bijgestaan door de minister van Volksgezondheid, Welzijn en Sport (VWS), tijdens persconferenties naar buiten wat er in de ministerraad was besloten.

Nederland heeft een nationaal Ministerie van Onderwijs, Cultuur en Wetenschap (OCW) met twee eigen bewindslieden, een minister voor Basis- en Voortgezet Onderwijs en Media (BVOM) en een minister van Onderwijs, Cultuur en Wetenschap (OCW) voor de overige beleidsterreinen. In het Nederlandse staatsbestel spelen de provincies in het besturen van scholen geen rol. Besluiten over het bouwen van schoolgebouwen worden wel op provinciaal niveau genomen. In het besturen van scholen speelt wel het gemeentebestuur een rol. De wethouder van onderwijs is, gecontroleerd door de gemeenteraad, verantwoordelijk voor het bestuur van de openbare scholen. De bijzondere scholen worden bestuurd door een privaat schoolbestuur, gekozen door de leden van een schoolvereniging. Het bestuur van de lokale scholen geschiedt binnen de kaders van de nationale onderwijswetgeving. Het ministerie van OCW houdt zicht op de kwaliteit van het onderwijs door inschakeling van de Inspectie van het Onderwijs. De bewindslieden laten zich adviseren door diverse adviesorganen. De onderwijsbesturen, schoolleiders en leraren hebben ieder eigen verenigingen die hun belangen behartigen en die ook reageren op besluiten die de overheid neemt inzake het onderwijs. Tussen het ministerie van OCW en deze verenigingen, die deels zijn georganiseerd op grond van levensbeschouwing, is georganiseerd overleg. Dat was er ook in de coronacrisis.

De maatregelen die de overheid tijdens deze crisis met de nodige omzichtigheid afkondigde, hadden geldingskracht voor het gehele Nederlandse onderwijs, zowel het openbaar als het bijzonder onderwijs. De maatregelen die de overheid in verband met de pandemie moest nemen met betrekking tot het onderwijs waren ingrijpend. Tweemaal werd besloten tot het sluiten van de basisscholen en de scholen voor voortgezet onderwijs (in maart 2020 en in december 2020). $\mathrm{Na}$ twee keer een sluiting van enkele maanden werden de scholen stapsgewijs heropend. Voor de heropende scholen golden onverkort de algemene basisregels. Bij het opleggen van de maatregelen werd benadrukt dat de Nederlandse burgers zich samen aan de regels moesten houden en dat overtreding ervan zeer schadelijke gevolgen zou hebben. De bewindslieden benadrukten herhaaldelijk het doel van de maatregelen, ook die in het onderwijs: bescherming van de zwakken en ontlasting van het zorgpersoneel. Zij gaven er blijk van dat zij besef hadden van de schadelijke gevolgen die de coronamaatregelen zouden hebben voor het onderwijs en speciaal voor kinderen en jongeren: de leer- en ontwikkelingsachterstanden die zouden ontstaan, onveilige thuissituaties waarin kinderen terecht zouden kunnen komen en de toenemende druk op de leraren. De overheid stelde in januari 2021 een groot bedrag beschikbaar voor het onderwijs om de schadelijke gevolgen van de coronacrisis, ook op langere termijn, aan te kunnen pakken.

De debatten die in de Tweede Kamer over de coronamaatregelen werden gevoerd, waren soms heftig, maar doorgaans accepteerden de Kamerleden de genomen besluiten, al dan niet met amendementen. Dat geldt ook voor de speciale wetsvoorstellen die nodig waren om vergaande coronamaatregelen te nemen. Nederlandse burgers kwamen echter tegen bepaalde maatregelen in verzet door buitenparlementaire acties op te zetten en rechtszaken tegen de staat te voeren. In alle gevoerde rechtszaken werd de staat echter in het gelijk gesteld (Zwolsman 2021:2). De besluiten die met betrekking tot het onderwijs werden genomen, waren soms reactief en liepen niet altijd gelijk op met besluiten die voor andere sectoren dan het onderwijs werden genomen (Remie 2020:4-5). Daarom zocht een deel van de scholen soms mogelijkheden om op een eigen manier met de maatregelen om te gaan. Hoewel zowel de schoolsluitingen als de heropeningen discussies opleverden in het onderwijs (Veldhuis 2021:10), is het niet tot grote ongeregeldheden in het onderwijs gekomen. Het is zelfs zo dat in de Nederlandse samenleving het draagvlak voor de maatregelen van de overheid groot was (De Klerk et al. 2021:167).

Tijdens de twee perioden van schoolsluiting schakelden scholen over op afstandsonderwijs. Daarin werden ze ondersteund door het ministerie van OCW. In de perioden waarin de scholen weer open waren, stelde de overheid beschermingsmiddelen en zelftests beschikbaar. Dat neemt 
echter niet weg dat de coronacrisis negatieve gevolgen heeft (gehad) voor het onderwijs. De Inspectie van het Onderwijs (2021a:13) constateert dat er aanhoudende zorg is over de kwaliteit en de continuitteit van het onderwijs. Schoolleiders constateerden in het najaar van 2020 bij dertien procent van de basisschoolleerlingen achterstanden, niet alleen in werkhouding, maar ook in basisvaardigheden (Inspectie van het Onderwijs 2021b:41). Bij leerlingen die minder deelnamen aan het onderwijs (zowel fysiek als op afstand) werden meer leerachterstanden geconstateerd dan bij leerlingen die meer deelnamen (Inspectie van het Onderwijs 2021b:46). In het voorjaar van 2021 leek de vertraging in de cognitieve ontwikkeling van leerlingen te zijn ingelopen (Impactteam Corona en onderwijskwaliteit 2021:4).

\section{De situatie in Zuid-Afrika}

Zuid-Afrika heeft een republikeinse democratische regering met een president als staatshoofd en een kabinet als uitvoerend gezag (Vos et al. 2021:52-53). De staatsinrichting vertoont trekken van een federaal stelsel, in zoverre er negen provincies zijn, met ieder een eigen provinciale regering. In vergelijking met andere federale stelsels in de wereld, zoals de Verenigde Staten van Amerika, is de macht van de provincies echter zeer beperkt (vgl. bv. Mathekga 2021:83, 86). Er bestaan bijvoorbeeld nationale politiediensten en de belasting wordt centraal geheven.

Het onderwijs wordt in Zuid-Afrika bestuurd op drie niveaus, namelijk door de centrale regering, de provinciale regering en de individuele onderwijsinstellingen. Op nationaal (centraal) vlak wordt de Minister van Basiese Onderwys krachtens de Nasionale Onderwysbeleidwet, Wet 27van 1996, gemachtigd om nationale normen en standaarden af te kondigen voor onderwijsorganisatie, -bestuur en -monitoring (vgl. Vos et al. 2021:63-64).

Het Nasionale Departement van Basiese Onderwys heeft de taak om nationaal onderwijsbeleid en grondwetsbepalingen inzake het onderwijs te maken en te effectueren. Elk van de negen Zuid-Afrikaanse provincies heeft een provinciaal Ministerie van Onderwys. Provinciale wetgevers mogen met betrekking tot enkele aspecten van het schoolse onderwijs wetten afkondigen. Een nationale wet wordt gemaakt voor zaken die een uniforme invoering in het hele land vereisen, voor het opstellen van minimum standaarden voor levering van openbare diensten, voor aangelegenheden die slechts door uniforme normen of standaarden geregeld kunnen worden - aangelegenheden die te maken hebben met de economische eenheid en zaken van nationaal belang (Niemczyk et al. 2022; ter perse). Op instellingsvlak heeft iedere school een schoolbeheerraad die bestaat uit vertegenwoordigers van ouders, leerlingen, leraren, nietonderwijzend personeel, het schoolhoofd en door de schoolbeheerraad zelf gekozen leden van de gemeenschap (ibid.). De schoolbeheerraad beheert en bestuurt de school en doet aan het provinciale onderwijsdepartement aanbevelingen voor de aanstelling van leraren (ibid.).
Met inachtneming van de beperkingen die de president afkondigde, nam de nationale Minister van Onderwys, na consultatie van de provinciale onderwijshoofden en onderwijsvakbonden, de nodige maatregelen. Die bestonden uit het sluiten van de scholen voor lange perioden, zodat ze moesten overschakelen op afstandsonderwijs en leerlingen thuis moesten leren en meer dan voor het uitbreken van de pandemie op hun ouders steunden (Niemczyk, De Beer \& Steyn 2021:183-184).

In het algemeen waren de onderwijsvakbonden en de ouders onwillig om de scholen te snel weer te openen vanwege de gezondheidsrisico's (Mthethwa 2021).

De scholen kregen bij de schoolsluiting en de overschakeling naar afstandsonderwijs geen steun van de centrale overheid (Mohamed 2021). Bovendien faalde de overheid soms in het verstrekken van de persoonlijke beschermingsmiddelen die nodig waren bij heropening van de scholen (ibid.). Alle tekenen wijzen erop dat de overschakeling naar afstandsonderwijs een nadelige uitwerking heeft gehad. Enkele maanden na de aanvang van de pandemie wees een uitgebreid onderzoek uit dat 29 procent van de leerlingen geen enkel contact met hun leraren meer had, dat 79 procent van de scholen die afhankelijk zijn van schoolgeld niet in staat waren om dat in te vorderen en dat 51 procent van de scholen niet in staat was om de leerlingen van huiswerk te voorzien (Slatter 2020:6-7). Scholen en gemeenschappen die zich aan de verkeerde kant van de digitale scheidslijn bevinden, zijn door de maatregelen in de crisissituatie het meest benadeeld, waardoor de ongelijkheid in het onderwijs is vergroot (Mohamed 2021). Medio 2021 was het duidelijk dat de pandemie en de manier waarop daarmee omgegaan werd een uiterst nadelige uitwerking had. Leerlingen raakten tussen 75 procent en een vol jaar achter in hun vorderingen (UNICEF 2021). Het gedeeltelijk bijwonen van lessen, perioden van schoolsluiting en schoolvrije dagen voor bepaalde groepen leerlingen hebben ertoe geleid dat leerlingen 54 procent van de onderwijstijd hebben gemist (ibid.). Tussen 400000 en 5000000 leerlingen hebben volgens de berichten in de periode van zestien maanden tot juli 2021 de school voortijdig verlaten (ibid.)

\section{Discussie}

Het referentiekader dat hierboven is weergegeven, richt zich op de situatie-ethiek. De situatie waarmee de overheden in beide landen te maken kregen, was de uitbraak van een pandemie die in potentie de kracht had (en nog steeds heeft) om de dood van miljoenen mensen te veroorzaken. De overheden, zowel de bewindslieden als de onderwijsbestuurders, hebben onmiddellijk de gevaren van de situatie ingezien en hun plicht gedaan door maatregelen te nemen die erop gericht waren om de verspreiding van het virus in te dammen en overbelasting van de gezondheidszorg te voorkomen. In dit proces, de afkondiging van een ramptoestand, verschillende beperkingen ('lockdowns') (ZuidAfrika) en een strenge lockdown (zelfs met een avondklok) (Nederland), is ook het functioneren van het onderwijs tot in de 
kern geraakt. Dat heeft kunnen gebeuren vanwege het feit dat de overheid het onderwijs financiert en daarmee ook verantwoordelijkheid draagt voor het onderwijs. Scholen waren dus verplicht om overheidsmaatregelen uit te voeren.

Die overheidsmaateregelen waren gedurende het eerste jaar van de pandemie (maart 2020-juni 2021) zeer ingrijpend, ook voor het onderwijs in Nederland en Zuid-Afrika. Maar in beide landen werden de maatregelen niet genomen vanuit een onderwijskundige-pedagogische achtergrond. Dat naast deze overeenkomst de uitwerking en de impact van de maatregelen verschilden, is te verklaren vanuit het contrast tussen beide landen. Nederland is een geografisch gezien klein, hoogontwikkeld land, met een zeer uitgewerkte overlegcultuur waar de wet- en regelgeving met betrekking tot het onderwijs volledig door de nationale overheid uitgevoerd wordt. Zuid-Afrika is een relatief groot ontwikkelingsland, waarin het staatsbestel veel meer hiërarchisch en centralistisch is uitgewerkt en het onderwijsbestuur ook op regionaal/provinciaal niveau geregeld is. Het valt te verwachten dat dergelijke verschillen bijdragen aan een verschillend omgaan met de crisissituatie in beide landen. Deze verschillen worden opgespoord aan de hand van de onderzoeksvraag: Hebben de verantwoordelijken voor het onderwijs gedurende het eerste jaar van de crisisperiode het schoolse onderwijs op de meest effectieve, empathische en liefdevolle wijze bestuurd en behartigd?

In Zuid-Afrika hebben de overheidsmaatregelen, veel meer dan in Nederland, nadelig gewerkt, vooral in meer afgelegen, onderontwikkelde en achtergebleven gemeenschappen. Het contact tussen leraren en leerlingen is in die gemeenschappen feitelijk compleet weggevallen en er zijn bij deze leerlingen aanzienlijke leerachterstanden ontstaan. In de meer bevoorrechte gemeenschappen waren de scholen in staat om afstandsonderwijs te geven, maar de ouders van leerlingen aan sommige van deze scholen konden geen schoolgeld betalen door verlies van werk (bv. in de drankhandel of het toerisme). De afwezigheid van technologie in de meer achtergebleven gemeenschappen zorgde voor relatief grote schooluitval, terwijl deze in de meer bevoorrechte gemeenschappen relatief gering was. Leerachterstanden zijn er echter in alle scholen, in meerdere of mindere mate. Schade voor scholen en belanghebbenden werd ook veroorzaakt door de onvoorspelbaarheid van de overheidsbesluiten met betrekking tot het al dan niet sluiten van de scholen.

In Nederland is het contact tussen leerlingen en leraren, zeker tijdens de eerste schoolsluiting, sterk verminderd, maar niet totaal weggevallen. De goede infrastructuur droeg eraan bij dat zij elkaar digitaal konden bereiken. Er zullen zeker schadelijke effecten zijn voor leerlingen, maar uiteindelijk blijken de leerachterstanden niet dramatisch te zijn. Het innen van schoolgeld is in Nederland niet aan de orde en van schooluitval is nauwelijks sprake.

In Nederland zijn de scholen tweemaal gesloten voor een periode van enkele maanden, maar niet de gehele periode van de pandemie. Toen de scholen gesloten waren, was dat geen totale schoolsluiting. De overheid zorgde ervoor dat kinderen van ouders met beroepen in de zorg wel naar school konden, zodat de ouders naar hun werk konden. Ook kinderen in een lastige (bedreigende) thuissituatie en de leerlingen die eindexamen moesten doen, mochten naar school. Tijdens de schoolsluiting werden er dus heel bewust uitzonderingen gemaakt. Dat geeft aan dat de Nederlandse overheid aandacht had voor kwetsbare leerlingen en ouders. In de Zuid-Afrikaanse situatie, waarin er sprake was van een lange, totale schoolsluiting, lag dat heel anders. Als gevolg van beperkte financiële en materiële middelen werden leerlingen, leraren en ouders niet of nauwelijks ondersteund.

Zuid-Afrikaanse onderwijsorganisaties (zoals de Federasie van Suid-Afrikaanse Skoolbeheerliggame) en onderwijsvakbonden zijn van mening dat zij niet voldoende betrokken waren bij het nemen van de maatregelen en dat hen zelfs het recht is ontnomen om autonome besluiten te nemen over sluiting en opening van scholen. De Nederlandse overlegcultuur werkte ook in de crisisperiode. Onderwijsorganisaties hadden veel en goed overleg met de Minister van Basis- en Voortgezet Onderwijs en Media. Zij waren niet altijd tevreden met de maatregelen die werden genomen, maar ze beklaagden zich niet over te weinig overleg en betrokkenheid.

De Nederlandse overheid heeft ervoor gezorgd dat leraren ondersteuning kregen bij het geven van online onderwijs, bijvoorbeeld door deskundigen te stimuleren hun kennis in bruikbare vorm beschikbaar te stellen. Er is 8,5 miljard euro beschikbaar gesteld voor het onderwijs om achterstanden weg te werken. In Zuid-Afrika werd de bij ouders, onderwijsorganisaties en vakbonden aanwezige kennis niet voldoende benut. Het ontbrak ook aan actieve ondersteuning van thuisonderwijs, online-onderwijs en werkende ouders door de overheid.

In de persconferenties van de Nederlandse bewindslieden ging het vaak over het onderwijs, de scholen, de ouders, de leerlingen. De bewindslieden toonden empathie voor hen en zij spraken hen soms heel direct toe. Er was een speciale kinderpersconferentie waarin kinderen direct met de bewindslieden konden communiceren. In Zuid-Afrika zijn de onderwijszaken behartigd op eenzelfde manier als andere onderdelen van de samenleving. De president heeft slechts bij enkele gelegenheden nadrukkelijk verwezen naar het onderwijs, maar hij heeft ouders, leraren en leerlingen nooit rechtstreeks aangesproken of bemoedigd.

De 'één maatregel voor iedereen'-benadering in Zuid-Afrika werkte nadelig uit voor scholen die niet (hard) werden getroffen door uitbraken van het coronavirus. Het gevolg daarvan is dat er ook bij leerlingen op die scholen grote leerachterstanden optraden, die moeilijk weg te werken zijn. In Nederland troffen de maatregelen ook zonder uitzondering alle scholen. Maar ze werden niet rigide toegepast. In beide landen werden de schoolsluitingen opgeheven zodra de besmettingsgraad dat mogelijk maakte. Bovendien bleven in Nederland, maar niet in Zuid-Afrika, ook in strenge 
lockdownperioden, scholen voor bepaalde groepen leerlingen toegankelijk.

\section{Conclusie}

Geconcludeerd kan worden dat de overheden in beide landen de gevaren van de situatie goed hebben ingeschat, hun morele plicht zijn nagekomen en morele deugdelijkheid aan de dag hebben gelegd, maar ook weinig ervaring hadden in het optreden tijdens een pandemie zoals die zich voordeed in 2020-2021. Volgens de situatie-ethiek hebben de overheden juist gehandeld, maar zij deden dit meer vanuit medischklinische overwegingen dan vanuit onderwijskundigpedagogische. Daarom schortte het bij de Zuid-Afrikaanse overheid, meer dan bij de Nederlandse, aan gevoeligheid voor de bijzondere eisen van onderwijs en opvoeding in de moeilijke omstandigheden. Dit gebrek aan empathie heeft voor Zuid-Afrika een zeer schadelijke werking gehad voor het onderwijs.

Vanuit het perspectief van de vergelijkende onderwijskunde vallen er tenminste vier lessen te leren uit de bovenstaande vergelijking. Ten eerste is uit het eerste jaar van de pandemie opnieuw gebleken dat de onderwijssector geen autonomie bezit en dat scholen in wezen door de staatsoverheid beheerd en bestuurd worden. Individuele scholen konden niet besluiten tot sluiting of openstelling. Deze besluiten werden door de staatsoverheid voor de scholen genomen. Ten tweede werd duidelijk dat de koude klinisch-medische besluitvorming met betrekking tot het onderwijs een warme, empathische en onderwijskundigpedagogische benadering van het onderwijs niet kan vervangen. Ten derde is gebleken dat één maatregel voor allen niet zonder meer moreel goed is, omdat deze geen rekening houdt met de contextuele verscheidenheid van het land en van de verschillende scholen met hun schoolbevolking. Ten laatste toont de vergelijking aan dat de overheid niet verstandig met het onderwijs en met scholen kan omgaan, als zij niet van binnenuit kennis heeft van onderwijskundige en pedagogische aangelegenheden, zoals ouderbetrokkenheid, de vereisten voor thuis-, online- en afstandsonderwijs en - zoals de situatie in ZuidAfrika aangetoond heeft - de bijzondere behoefte van achtergebleven schoolgemeenschappen.

\section{Erkenning \\ Concurrerende belangen}

De auteurs verklaren hierbij dat zij geen financiële of persoonlijke relatie hebben met enige partij die hen ten nadele of ten voordele kon beïnvloeden bij het schrijven van dit artikel.

\section{Auteursbijdragen}

N.A.B. (Driestar hogeschool) was verantwoordelijk voor de beschrijving van de situatie in Nederland. Hij vertaalde de tekst in het Nederlands, formatteerde en bewerkte de eindversie. J.L.v.d.W. (Noordwes-Universiteit) verzorgde het onderdeel over het theoretische raamwerk. C.C.W. (Noordwes-Universiteit) beschreef de situatie in Zuid-Afrika. Alle drie de auteurs werkten samen aan de overige gedeeltes van dit artikel.

\section{Ethische overwegingen}

Dit artikel hield zich aan al de ethische normen voor wetenschappelijk onderzoek zonder rechtstreeks contact met mensen of dieren.

\section{Fondseninformatie}

De auteurs hebben geen specifieke subsidie ontvangen van een financieringsinstantie in de publieke, commerciële of non-profit sector

\section{Beschikbaarheid van data}

Het delen van gegevens is niet van toepassing op dit artikel omdat er geen nieuwe gegevens zijn zijn gemaakt of geanalyseerd in dit onderzoek.

\section{Vrijwaring}

De meningen die in dit artikel eventueel tot uitdrukking komen, zijn die van de auteurs en reflecteren niet noodzakelijkerwijs het officiële beleid van de instituten waaraan de auteurs verbonden zijn.

\section{Literatuurverwijzingen}

Crossley, M., 2014, 'Global league tables, big data and the international transfer of educational research modalities', Comparative Education 50(1), 15-26. https:// doi.org/10.1080/03050068.2013.871438

De Klerk, M., Olsthoorn, M., Plaisier, I., Schaper, J. \& Wagemans, F., 2021, Een jaar met corona, Sociaal en Cultureel Planbureau (SCP), Den Haag.

Frame, J., 2008, The doctrine of the Christian life, P\&R Publishing, Phillipsburg, NJ.

Geisler, N.L., 2010, Christian ethics, Baker Academic, Grand Rapids, MI.

Heiberg, P.J., 1970, 'Die grondslag van Christelike opvoeding en onderwys in SuidAfrika', in R.J. Raath (ed.), ' $n$ Volk besin oor sy opvoeding en onderwys, pp. 32-57, Interkerklike Uitgewerstrust, Kaapstad.

Impactteam Corona en onderwijskwaliteit, 2021, Geen tijd te verliezen, PO-raad, Utrecht.

Inspectie van het Onderwijs, 2021a, De staat van het onderwijs, Inspectie van het Onderwijs, Utrecht.

Inspectie van het Onderwijs, 2021b, Technisch rapport corona en het onderwijs, Inspectie van het Onderwijs, Utrecht.

Koonce, J., 2018, 'Critical race theory and caring as channels for transcending borders between an African-American professor and her Latina/o students', International Journal of Multicultural Education 20(2), 101-116. https://doi.org/10.18251/ ijme.v20i2.1432

Lahti, D.C. \& Weinstein, B.S., 2005, 'The better angels of our nature: Group stability and the evolution of moral tension', Evolution and Human Behavior 26, 47-63. https://doi.org/10.1016/j.evolhumbehav.2004.09.004

Liautaud, S., 2021, The power of ethics, Simon \& Schuster, London.

Mathekga, R., 2021, The ANC's last decade: How the decline of the party will transform South Africa, Kaapstad, Tafelberg.

Mayes, T. \& De Freitas, S., 2007, 'Learning and e-learning', in H. Bentham \& R. Sharpe (eds.), Rethinking pedagogy for a digital age, pp. 11-24, Routledge, London.

Mitchell, C.B., 2013, Ethics and moral reasoning, Crossway Books, Wheaton, IL.

Mohamed, S., 2021, 'South Africa: COVID-19 pushes inequality in schools to crippling new level, risks a lost generation of learners', Amnesty International Press Release 15 February 2021, viewed 15 November 2021, from https://www.amnesty.org/ en/latest/press-release/2021/02/south-africa-covid19-pushes-inequality-in schools-to-crippling-new-level-risks-a-lost-generation-of-learners/.

Mthethwa, C., 2021, 'Schools reopening: Unions, parents fear sending children back to school', News 24, 24 Julie 2021, viewed 15 November 2021, from https://www. news24.com/news24/southafrica/news/schools-reopening-unions-parents-fearsending-children-back-to-school-20210724. 
Niemczyk, E.K., De Beer, Z.L. \& Steyn, H.J., 2021, 'The challenges posed by COVID-19 to the BRICS education systems: Lessons to be learned', Perspectives in Education 39(1), 173-188. https://doi.org/10.18820/2519593X/pie.v39.i1.11

Niemczyk, E.K., De Beer, Z.L., Vos, D., Nhlapo, V.A., Steyn, H.J. \& Wolhuter, C.C., 2022, Die Suid-Afrikaanse onderwystelsel: Kernkenmerke, Noordbrug. Keurkopie, Ter Perse.

Paley, C., 2021, Beyond bad, Coronet, London.

Pinker, S., 2019, Enlightenment now, Penguin, London.

Poythress, V., 2006, Redeeming science. A God-centered approach, Crossway Books, Wheaton, IL.

Remie, M., 2020, 'Ook op scholen zijn er steeds meer meningen over corona', NRC Handelsblad, 20 oktober, pp. 4-5.

Slatter, L., 2020, 'Unies: Dié skole mag nie open', Rapport, 16 Augustus, pp. 6-7.

Stoker, H.G., 1967, Oorsprong en rigting I, Tafelberg, Kaapstad.

Strauss, D.F.M., 2009, 'Social space: Philosophical reflections', South African Journal of Higher Education 23(4), 760-792. https://doi.org/10.4314/sajhe. v23i4.51069

Stromquist, N., 2002, Education in a globalized world: The connectivity of economic power, technology, and knowledge, Rowman \& Littlefield, Lanham, MD.

Thanh, N.C. \& Thanh, T.T.L., 2015, 'The interconnection between interpretist paradigm and qualitative methods in education', American Journal of Educational Science $1(2), 24-27$

Thompson, M., 2018, Ethics for life, John Murray Learning, London.
UNESCO, 2020a, Covid-19 educational disruption and response, viewed 22 September 2021, from https://en.unesco.org/covid19/educationresponse/.

UNESCO, 2020b, Learning never stops: In response to Covid-19, viewed 22 September 2021, from https://en.unesco.org/covid19/educationresponse/globalcoalition/.

UNESCO, 2021, From disruption to recovery, viewed 22 September 2021, from https://en.unesco.org/covid19/educationresponse.

UNICEF, 2021, Persverklaring, viewed 22 September 2021, from https://www.unicef. org/press-releases/learners-south-africa-one-school-year-behind-where-theyshould-be.

Veldhuis, P., 2021, 'Scholen gaan open, leraren boos', NRC Handelsblad, 25 mei, p. 10.

Vorster, J.M., 2017, Ethical perspectives on human rights, Theological Publications, Potchefstroom.

Vos, D., De Beer, Z.L., Nhlapo, V.A. \& Khumalo, J.B., 2021, 'The education system of South Africa', in C.C. Wolhuter \& H.J. Steyn (eds), World education systems entering the twenty-first century, pp. 44-79, Keurkopie, Noordbrug.

Wiseman, A.W., 2010, 'The use of evidence for education policy making: Global contexts and international trends', Review of Research in Education 34(1), 1-24.

Wolhuter, C.C., 2021, 'Comparative and international education: A field of scholarship exploring critical issues in contemporary education', in C.C. Wolhuter \& H.J. Steyn (eds.), Critical issues in education systems: Comparative-international perspectives, pp. 1-20, Keurkopie, Noordbrug.

Zwolsman, N., 2021, 'Hof: avondklok was toch voldoende onderbouwd', NRC Handelsblad, 26 februari, p. 2 